\title{
The cyclical relations between traded property stock prices and aggregate time- series
}

Article

Accepted Version

Brooks, C., Tsolacos, S. and Lee, S. (2000) The cyclical relations between traded property stock prices and aggregate time-series. Journal of Property Investment \& Finance, 18 (6). pp. 540-564. ISSN 1463-578X doi:

https://doi.org/10.1108/14635780010357532 Available at https://centaur.reading.ac.uk/35972/

It is advisable to refer to the publisher's version if you intend to cite from the work. See Guidance on citing.

Published version at: http://dx.doi.org/10.1108/14635780010357532

To link to this article DOI: http://dx.doi.org/10.1108/14635780010357532

Publisher: Emerald Group Publishing Limited

All outputs in CentAUR are protected by Intellectual Property Rights law, including copyright law. Copyright and IPR is retained by the creators or other copyright holders. Terms and conditions for use of this material are defined in the End User Agreement.

www.reading.ac.uk/centaur 
Central Archive at the University of Reading

Reading's research outputs online 
This article is (c) Emerald Group Publishing and permission has been granted for this version to appear here (centaur.reading.ac.uk). Emerald does not grant permission for this article to be further copied/distributed or hosted elsewhere without the express permission from Emerald Group Publishing Limited. The definitive version can be found at http://www.emeraldinsight.com/journals.htm?articleid=845112 


\title{
The Cyclical Relations between Traded Property Stock Prices and Aggregate Time-Series*
}

\author{
Chris Brooks (corresponding author) \\ ISMA Centre, Department of Economics, University of Reading, Whiteknights, \\ Reading, RG6 6BA, UK \\ Sotiris Tsolacos \\ Jones Lang LaSalle, 22 Hanover Square, London, W1A 2BN, UK \\ Stephen Lee \\ Department of Land Management University of Reading, Whiteknights, \\ Reading, RG6 6AW, UK
}

\begin{abstract}
This paper examines the cyclical regularities of macroeconomic, financial and property market aggregates in relation to the property stock price cycle in the UK. The Hodrick Prescott filter is employed to fit a long-term trend to the raw data, and to derive the short-term cycles of each series. It is found that the cycles of consumer expenditure, total consumption per capita, the dividend yield, and the long-term bond yield are moderately correlated, and mainly coincident, with the property price cycle. There is also evidence that the nominal and real Treasury bill rates and the interest rate spread lead this cycle by one or two quarters, and therefore that these series can be considered leading indicators of property stock prices. This study recommends that macroeconomic and financial variables can provide useful information to explain and potentially to forecast movements of property-backed stock returns in the UK.
\end{abstract}

\section{May 2000}

J.E.L. Classifications: C32, C52

Keywords: UK real estate returns aggregate time series, macroeconomic and financial factors, cycles, co-movements.

\footnotetext{
* The authors are grateful to the Editorial Board of this journal, and an anonymous referee, for useful comments on a previous version of this paper. The usual disclaimer applies.
} 


\section{The Cyclical Relations between Traded Property Stock Prices and Aggregate Time-Series}

\section{Introduction}

In existing research on property return predictability authors have deployed alternative methodologies and different macroeconomic and financial variables to investigate the variation in property stock returns. These studies have provided useful insight into the forces that cause variation in property stock prices and returns through time ${ }^{1}$. The expected linkages between the macroeconomic and financial variables considered and property stock returns are based on the extensive research work on general stock and bond returns ${ }^{2}$. In the property returns literature, the empirical estimates provide a varying degree of support to the a priori economic relationships and the role of specific variables. It could be argued that the empirical findings are, to a degree, contingent on the particular methodologies, the data series and the sample periods employed in deriving the estimates. Therefore, additional empirical evidence on the expected relationships is required. There is also a need for a formal examination of how the variables that explain a priori the variation in property stock returns move over the property return cycle in practice across different market environments.

The findings of an investigation of the stylised facts of property stock price cycles are expected to improve existing knowledge on the cyclical behaviour of property prices. The contribution can be made in several directions. First, evidence is generated on the cyclical

\footnotetext{
${ }^{1}$ Most of the empirical work in this area has been carried out in the US context. This may reflect the relatively greater significance of property investment trusts (REITs) and other public property asset vehicles in the US. The main studies include those of Chan et al (1990), Liu and Mei (1992), McCue and Kling (1994); Mei and Liu (1994); Peterson and Hsieh (1997), Ling and Naranjo (1997) and Eppli et al (1998). The subject of property return predictability is under-researched in the UK. Three studies have attempted to close this gap (RICS, 1994; Lizieri and Satchell, 1997 and Brooks and Tsolacos, 1999).

2Indicative studies in this extensive literature are those of Chen et al (1986), Fama and French (1989; 1992), Pesaran and Timmermann (1995), Chung and Zhou (1996).
} 
regularities between property stock prices and the variables that are chosen on an a priori basis to explain the variation in the former. An examination of these co-movements can illustrate to what extent positive or inverse co-movements and lead-lag relationships between the cycles of property prices and the different time-series exist. Second, the analysis identifies time-series that can be used as leading indicators of property price movements. From an analyst's point of view, an exercise of establishing leading indicators has profound merits in the predictability of property stock prices. Third, the findings could inform the construction of models of property stock prices and returns, as the causal relationships assumed in econometric models needs to hold in practice.

This study provides the stylised facts of the property stock price cycle in the UK. It aims to examine the cyclical properties of a small set of variables, comprising real economy, financial and property market time-series, in relation to the property stock price cycle. As in all relevant literature, it is assumed that movements of property asset prices might be the result of changes in economic, business and real property market conditions. The selected variables are considered to contain information on economic and property market trends. A meaningful analysis of the cyclical properties of property stock prices in relation to the cycle of these time-series requires that variables are appropriately detrended in order to extract the relevant cyclical component from the raw data. The methodology suggested by Hodrick and Prescott (1980) is employed in the present study; the Hodrick Prescott filter is a detrending technique that is widely used in the relevant economics literature.

The remainder of the paper is organised in five sections. The following section outlines the methodology. It discusses the expected relationships between the aggregates and property backed stock prices. This section also outlines the procedure to obtain the short-term cyclical 
variation in each series from the raw data. Section three describes the variables and the data. In section four, the cyclical components of certain issues are illustrated graphically. The results of the statistical analysis are reported in section five. In the final section the implications of the findings for property price modelling and forecasting are discussed.

\section{Methodology}

\subsection{A priori relationships}

In this section, we describe our rationale for selecting certain a priori variables as explanatory factors for movements in property stock returns. The starting point in discussing the relationships between the selected time-series and property stock prices is that the cyclical movements of the latter are generated by the changing economic-business conditions and by the performance of the underlying property market (Mei and Liu, 1994; McCue and Kling, 1994; Brooks and Tsolacos, 1999). The selection of the aggregate time-series to examine the stylised facts of the property stock price cycle in the UK is based upon theoretical intuition and the group of variables that have been used in related existing empirical work. The set of variables comprises macroeconomic and financial time-series that are expected to track the changing business climate and series that reflect property market conditions. More specifically the following variables are included: real gross domestic product, real consumer expenditure, real consumer expenditure per capita, inflation rate, unexpected inflation, dividend yield, nominal and real short-term interest rates, nominal long-term interest rate, interest rate spread, real commercial property rents and the average all property yield. These variables are regularly used in existing studies since it is assumed that they have predictive power for property stock price movements.

\subsection{Real Economy Variables}


Real gross domestic product, real consumer expenditure and real consumer expenditure per capita show trends in the real economy. The cyclical movements of these aggregates are expected to correlate positively with the turnover of the property sector and the variation in property backed asset prices. A higher turnover is the result of a buoyant economy that would lead to rising property asset prices. The use of the consumption series in the predictability of stock returns has long been documented in a number of relevant studies (Breeden, 1979; Hansen and Singleton, 1983; Ferson, 1983; Breeden et al 1989; Ferson and Harvey, 1991). Real gross domestic product includes the effect of both the industrial and monetary sectors on broader economic activity. Moreover, gross domestic product captures trends not only in the industrial sector but also in the service sector and the business of retailing. Roll and Ross (1980) have argued that fundamental economic aggregates, such as the gross domestic product, are important determinants of the systematic economic risk and prices in the stock market. It is therefore expected that the three real economy series will show positive cyclical co-movements with the property price cycle.

\subsection{Inflation Rates}

Actual and unanticipated inflation rates are included in studies of stock return behaviour because asset prices are assumed to reflect cash flows. Chen et al (1986), in their study of the links between economic variables and asset prices, argue that both nominal and real factors are responsible for the changes in expected cash flows. Nominal forces include inflation measures. Furthermore, these authors note that if the pricing is done in real terms, unanticipated inflation will have a significant effect on stock returns. Ferson and Harvey (1991) claim that a premium should be added when pricing stocks that have exposure to unanticipated inflation. Following these lines of argument it is expected that property stock prices will be affected by the cash flow generated by underlying property assets. Since 
inflation is widely accepted to affect these cash flows (inflates their nominal value), a positive relationship can be argued between the inflation rate and property stock prices. For the same reason it is expected that property stock prices would adjust positively to unanticipated inflation. Of course, it could be argued that at periods of increasing inflation traders might expect interest rates to increase and choke off economic activity leading to lower realised property stock prices increases or even price falls.

\subsection{Dividend Yield}

The dividend yield is a financial ratio that proxies future business conditions. According to Fama and French (1988) the dividend yield is a noisy proxy for expected stock prices and returns because it partly reflects expected dividend growth. Optimism about future dividends produces high stock prices relative to current dividend and a low dividend yield (defined as the current dividend over current price). Falling dividend yields signal expectations about stronger future economic activity which is expected to have positive effects on the performance of property stocks. Therefore, dividend yields are expected to be related inversely to property stock prices.

\subsection{Interest Rates}

Short-term interest rates (nominal or real) indicate the directions of monetary policy and the intentions of the authorities to regulate aggregate domestic demand pressures and domestic economic activity. High (low) short-term interest rates could be the source of expectations about weaker (stronger) economic activity (suggesting a negative relationship between interest rates and property stock prices). Long-term interest rates can be seen as forward 
looking indicators which reflect the financial markets' assessment of underlying economic conditions and which cannot be directly influenced by national authorities. The variation in long-term interest rate is mainly effected by how financial markets assess the prospects in terms of inflation, soundness of public finances, exchange rate stability and, of course, economic growth. Again an inverse relationship can be argued between long-term interest rates and property stock prices since low and stable long-term rates imply a future sound economic performance.

There has been an extended literature on interest rate spreads as possible indicators of future inflation and economic activity (see for example Laurent, 1988; Stock and Watson, 1989; Davis and Henry, 1993 and Hardouvelis, 1994). Bernanke (1990) has argued that interest rates and spreads contain information about the future course of the economy that is not included even in the index of leading indicators. Estrella and Hardouvelis (1991) claim that the slope of the yield curve can predict cumulative changes in real output for up to four years into the future (see also Chen, 1991). Proponents of spreads argue that exploiting the relationships between interest rates of different maturity (spreads) leads in most cases to an improvement in inflation and economic growth forecasts.

The interest rate spread or term structure is defined as the difference between the long-term and short-term interest rate. This spread is usually positive, that is the yield curve is upwards sloping. A flattening in the yield curve should be associated with lower property share prices and a steeper yield curve with higher prices. Estrella and Hardouvelis (1991) explain that a current short-lived monetary tightening would increase short-term interest rates but will have a relatively weaker effect on long-term rates (because it is expected to be short-lived), thus causing the yield curve to flatten. As current interest rates increase, investment activity is 
curbed resulting in lower future output. Thus both the current slope of the yield curve and growth in output decline, suggesting a positive association between the two variables.

\subsection{Property Rents and Yields}

Finally, the variation in property stock prices is also driven by the performance of the underlying property market (Mei and Liu, 1994, have examined this contention with inclusion of the capital rate). Current and anticipated property rents indicate property market conditions and the profitability of property investments. The prices of traded property assets are expected to move in proportion with rents. The current levels of actual rents may not, however, fully capture expected rents. The latter are more effectively reflected in property yields. More generally, the property yield series is used as an indicator of the expected conditions in commercial property markets. Lower yields result from a better performing property market and are expected to be related with higher property stock prices (inverse relationship).

\subsection{The cyclical component of the series}

Cycles in the present study refer to short-run fluctuations of the series around a smooth trend (Kydland and Prescott, 1990; Blackburn and Ravn, 1992). Any empirical study of the shortterm cyclical fluctuations between variables is conditioned on the way in which the analyst chooses to extract the trend from the observed series. There are several methods to detrend the original series and obtain its stationary component. These methods include the use of deterministic polynomial functions of time (eg quadratic trends), first differencing, or 
ARIMA models fitted to each individual series and other procedures ${ }^{3}$. In the present investigation the two-sided filter proposed by Hodrick and Prescott (1980) is used to extract the trend component. This procedure is the most commonly used detrending method in applied econometric work.

The Hodrick Prescott (HP) filter is a smooth trend that is fitted to the raw data. This filter provides a means to compute the trend or growth component of a non stationary time-series $\left\{\mathrm{y}_{\mathrm{t}}\right\}$ which is described by a growth $\left\{\mathrm{g}_{\mathrm{t}}\right\}$ and a cyclical $\left\{\mathrm{c}_{\mathrm{t}}\right\}$ component:

$$
\mathrm{y}_{\mathrm{t}}=\mathrm{g}_{\mathrm{t}}+\mathrm{c}_{\mathrm{t}}
$$

The HP procedure approximates $\left\{\mathrm{y}_{\mathrm{t}}\right\}$ by a smooth curve. In particular, this procedure constrains the smoothness of the growth component by setting the sum of squares of its second-order differences less than some number. According to this filter the trend component $\left\{g_{t}\right\}$ of a variable $\left\{y_{t}\right\}$ is the solution to the following least squares minimisation problem:

$$
\min \sum_{t=1}^{T}\left(y_{t}-g_{t}\right)^{2}+\lambda \sum_{t=2}^{T-1}\left[\left(g_{t+1}-g_{t}\right)-\left(g_{t}-g_{t-1}\right)\right]^{2}
$$

Equation (2) is the Lagrange function for minimising the sum of squares of the trend deviations, subject to the restriction that variations in the trend component are limited. The objective function (2) consists of two terms. The first one is a measure of fit. It is minimised for $y_{t}=g_{t}$ for all $t$. The second term is a measure of smoothness. It becomes zero when a change in $g_{t}$ is constant for all $t$, i.e. when $\left\{g_{t}\right\}$ is linear. Thus there is a trade-off between the two objectives of fit and smoothness and one must decide how much weight to place on each goal. The weighting factor is given by $\lambda$, which is the Lagrange multiplier associated with the smoothness constraint. The larger $\lambda$, the smaller the variations in the trend component will be.

\footnotetext{
${ }^{3}$ Most of these methods are presented in the relevant business cycle literature. Several studies have discussed in detail the HP filter as well as alternative procedures. These studies include Beveridge and Nelson (1981), Nelson and Plosser (1982), Shapiro and Watson (1988), Blanchard and Quah (1989), Brandner and Neusser (1992) and
} 
This factor must be set a priori. It has, however, been the practice to set the values of $\lambda$ as 400 for annual data, 1600 for quarterly data and 12,000 for monthly data.

As noted by Kydland and Prescott (1990), the HP-filter has several attractive features. An appealing feature is that it can accommodate time-series with changing mean growth rates. Moreover, the trend is a linear transformation of the original series that is identical for all series considered. Therefore, it is well-suited for comparison across many variables.

Initially, in this investigation the HP procedure is used to fit a smooth trend to all data series. It is customary to define the cyclical component of each series as the deviations of the actual values from the HP trend fitted to the series (that is, the cycle is defined as actual series minus the HP trend). The cyclical component of each series is required to be stationary. Augmented Dickey-Fuller tests (Dickey and Fuller, 1979; 1981) are carried out to test for unit roots in the HP cyclical components of each time-series. Following this standard methodology, the cyclical characteristics of the detrended variables are described in terms of cyclical comovements. These co-movements are identified with the method of cross-correlations. In this study, the cyclical co-movements between the HP property stock price cycle and the HP cycles of the selected variables are examined with the estimation of cross-correlations between the contemporaneous values of the HP property price cycle and up to three lagged and led values of the other variables. Longer lags could be tested, but market efficiency arguments would suggest that longer term relationships should not exist. The crosscorrelations will reveal whether a given variable is procyclical or countercyclical in relation to the reference property price cycle. A procyclical variable will tend to conform with and relate 
positively to the different phases of this cycle whereas a countercyclical variable will move inversely to the different phases of the property price cycle.

A procyclical or countercyclical variable leads, lags or is coincident with the property price cycle. When a variable has stronger lagged (led) correlations with the contemporaneous values of this cycle it is an indication that the former leads (lags) the latter. Furthermore, a variable that peaks or reaches a trough before (after) the peaks or troughs of the property price cycle signifies a leading (lagging) variable. In the case of coincident relationship the strongest correlation will be exhibited by the contemporaneous values of the cycles. Therefore, the computed cross-correlation coefficients between the contemporaneous values of the HP property asset price cycle and lagged and led values of the HP cycles of the economic, financial and property market series can be used to establish whether a series leads, lags or is coincident with the property price cycle.

It is possible to apply tests of significance to the individual cross-correlation coefficients using Fischer's exact test, which is asymptotically distributed as a standard normal variate under the null of no association. The test statistic is given by:

$$
z=\frac{0.5 \log [(1+r) /(1-r)]}{\sqrt{\frac{1}{N-3}}}
$$

where $N$ is the sample size, and $r$ is the estimated correlation coefficient. In this study, in the main $N=130$, so given the relevant critical values from the tables, we can class correlations bigger than 0.17 , and 0.23 to be significant at the $5 \%$ and $1 \%$ levels respectively. 


\section{Variables and data}

The study uses quarterly data. This is because data for the gross domestic product and the expenditure variables are available at this frequency only. The sample period is 1965 quarter 1 to 1998 quarter 2 . The start date represents the first observation available for the property stock price series used in this study. However, the data start date for a number of other variables is after 1965 quarter 1. All data, unless otherwise stated, are obtained form Primark Datastream.

\subsection{The traded property stock price series}

The property stock price series in this study is the index of property company share prices. The dataset for property company share prices is based on a market value-weighted index constructed by Primark Datastream. These companies hold properties in all commercial sectors. The index is based upon the top 26 property stocks traded on the London Stock Exchange. The relative weightings given to the component stock are updated on a monthly basis. The index is compiled monthly and takes the value of 100 in January 1965. In June 1998 the value of this index was 10,511. For conformity, since a number of the time-series are in percentage terms the series of property share prices is also expressed in percentage terms; this measure is the property stock return series used in other studies.

\subsection{Macroeconomic aggregates}

The gross domestic product is the total economy output measure and the data are provided in constant values and in the form of an index. Consumer expenditure refers to total consumer expenditure on durables and non-durable goods and services. The data are also available at constant prices. Total consumption per head is total consumer expenditure divided by the size 
of the population. This series is available in nominal values. It is converted into real terms using the all items retail price index.

\subsection{Inflation variables and the dividend yield}

The inflation rate variable is the annual percentage increase in the all items retail price index. The retail price index is monthly and is converted into a quarterly index by taking an average of the monthly values corresponding to each quarter. Inflation refers to the annualised change in the quarterly retail price index at each quarter (this is the actual or realised inflation rate). From this inflation rate we construct a measure of the unexpected inflation rate defined as the realised, annualised rate of inflation at each quarter minus the expected rate of inflation at that quarter. To estimate the expected rate of inflation we fit an autoregressive moving-average model to the actual inflation series ${ }^{4}$. The predicted (fitted) values of this model are considered to be the expected inflation rates. The difference between the actual rate of inflation at time $\mathrm{t}$ and the rate that was predicted for time $t$ at the previous period $(\mathrm{t}-1)$, produced the measure of the unexpected inflation at time t. The dividend yield is the dividend yield on all FTA AllShare index. It expresses the dividend per share as a percentage of the price.

\subsection{Interest rate variables}

The interest rate variables comprise nominal and real short-term rates and nominal long-term interest rates. The nominal short-term interest rate is the end of period UK three month Treasury Bill rate. The nominal long-term rate is the UK gross redemption yield on 20 year

\footnotetext{
${ }^{4}$ Using an auto-regressive moving-average (ARMA) methodology to replicate a time-series is very common in empirical studies in economics. The inflation series is not stationary and therefore an ARMA model could not be estimated directly. This methodology was applied to the stationary first differenced series of inflation (ARIMA model). Following the standard procedures to define the order of the autoregressive and moving average terms (relevant tables are available from the authors on request) the order of the ARIMA was found to be $(2,1,2)$ that is it contains two autoregressive and two moving average terms. This ARIMA model was used to predict the inflation rate one step ahead. From these predicted inflation rates in first differences the predicted (expected)
} 
gilts. The frequency of the original series is monthly. A quarterly series is derived from the monthly data by taking a simple average of the three monthly values in each quarter. From the quarterly short-term interest rates and the measures of actual and expected inflation three series for real short-term interest rates are constructed. The first series is obtained by deducting the annual realised rate of inflation at each quarter from the nominal Treasury Bill rate that quarter. The second series is the nominal Treasury Bill minus the expected rate of inflation (as defined earlier) the next period. Thus this measure of real interest rates at time $t$ is the nominal Treasury Bill rate at time $t$ minus the expected rate of inflation at time $(t+1)$ estimated at time t. The third measure used is that suggested by Lizieri and Satchell (1997). This is a ratio of the three month Treasury Bill rate to the realised inflation rate. This ratio takes the value of unity when nominal rates are equal to inflation rates. Values higher than one signify positive real interest rates rates (and vice versa when positive inflation rates are assumed). Lizieri and Satchell argue that the trade off in using this measure is loss of sensitivity for more robust results. Similar measures for real long-term interest rates are not constructed since the long-term yield incorporates expectations about the future inflation. The interest rate spread variable is defined as the difference between the long-term interest rate (yield on 20 year gilts) and the short term rate (nominal 3-month Treasury Bill rate).

\subsection{Property market variables}

Data for rental values and property yields are compiled by CB Hillier Parker. The CB Hillier Parker rent and yield indices provide a single overall measure of commercial property rental values and yields at the national level. They amalgamate the three national indices for shops, offices and industrials to form an overall index for all commercial property. The CB Hillier Parker data consist of open market rents and yields on carefully defined properties of a

inflation series was constructed. 
particular specification (generally modern standard properties on institutional leases) in over 700 locations across the standard geographical regions of Great Britain. The data represent valuers' views of market conditions based on market knowledge and available comparables. An overall market index is produced weighted by sector values. In December 1992 these weights were $44 \%$ offices, $41 \%$ shops and $15 \%$ industrials (weights in line with institutional investors holdings in these sectors). Further information about the nature of these indices can be found in Hoesli et al (1997) and Eichholtz et al (1995). The series of rents is in real terms.

The names of variables and a summary of their definitions are given below. 


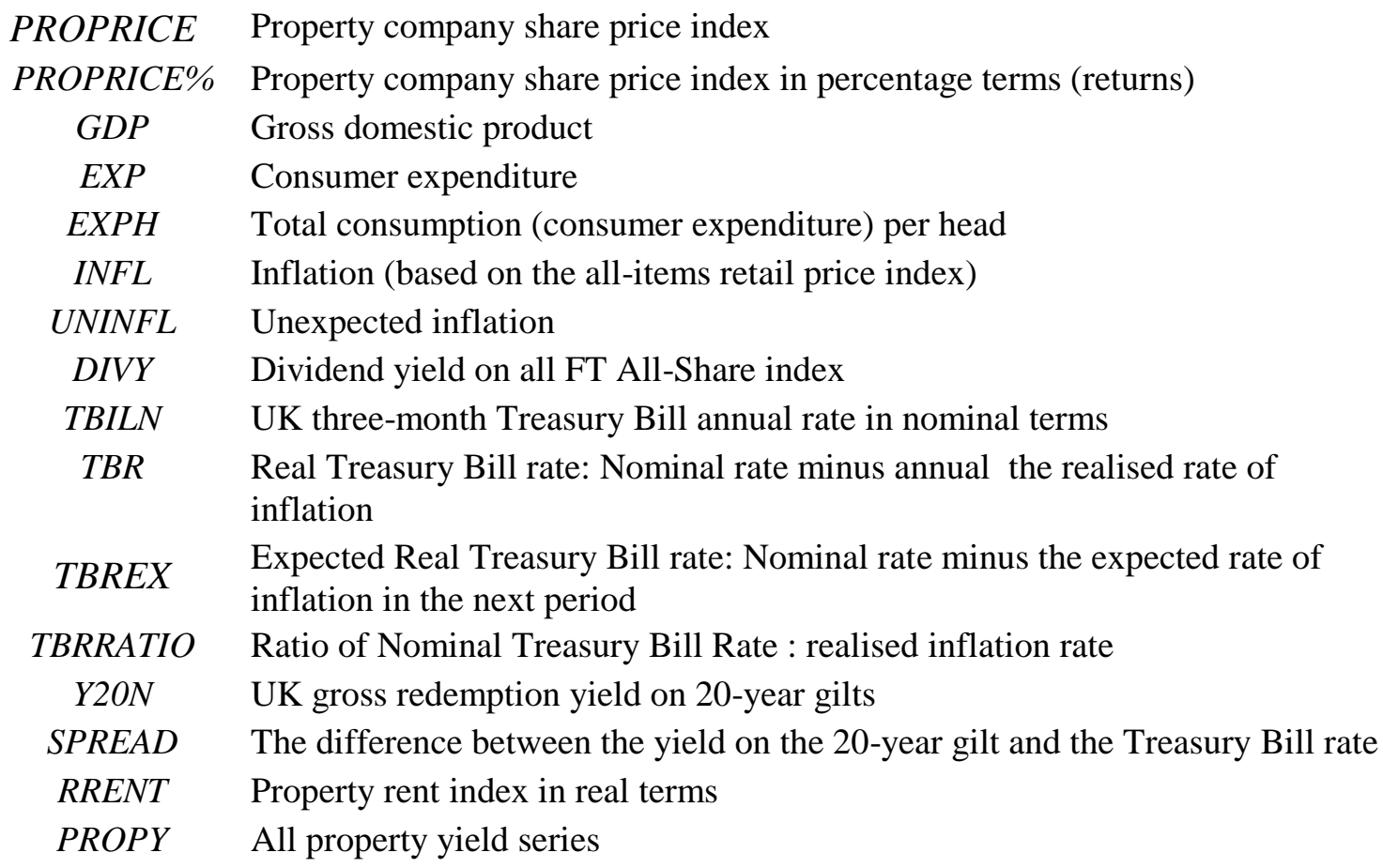

The above variables represent short-term cycles of the original series. The short-term cycles are defined as the original series minus the Hodrick Prescott long-term trend fitted into each of the series.

\section{Cyclical components}

This section provides a graphical illustration of the short-term cycles which are derived after fitting the HP trend in the raw data series. These cycles are shown for selected series: property share prices, GDP, inflation rates and nominal short-term interest rates. Figure 1 shows the actual property company share price index and the smooth trend produced by the HP-filter. Figure 2 depicts the short-term cyclical component of the series (the HP property share price cycle), that is deviations of the actual series from the HP trend. When the cycle line is above (below) the zero line it means that actual property stock price series was above (below) the HP long-term trend. An important feature of the data is that the volatility or variation of the short-term property share price cycle has increased substantially since the mid-1980s, both 
above and below the HP trend. These erratic adjustments in the price of traded property stocks could partly be the result of more volatile underlying forces both in the broad economy and the real property market.

Figure 1. Property share prices and HP trend

Index values

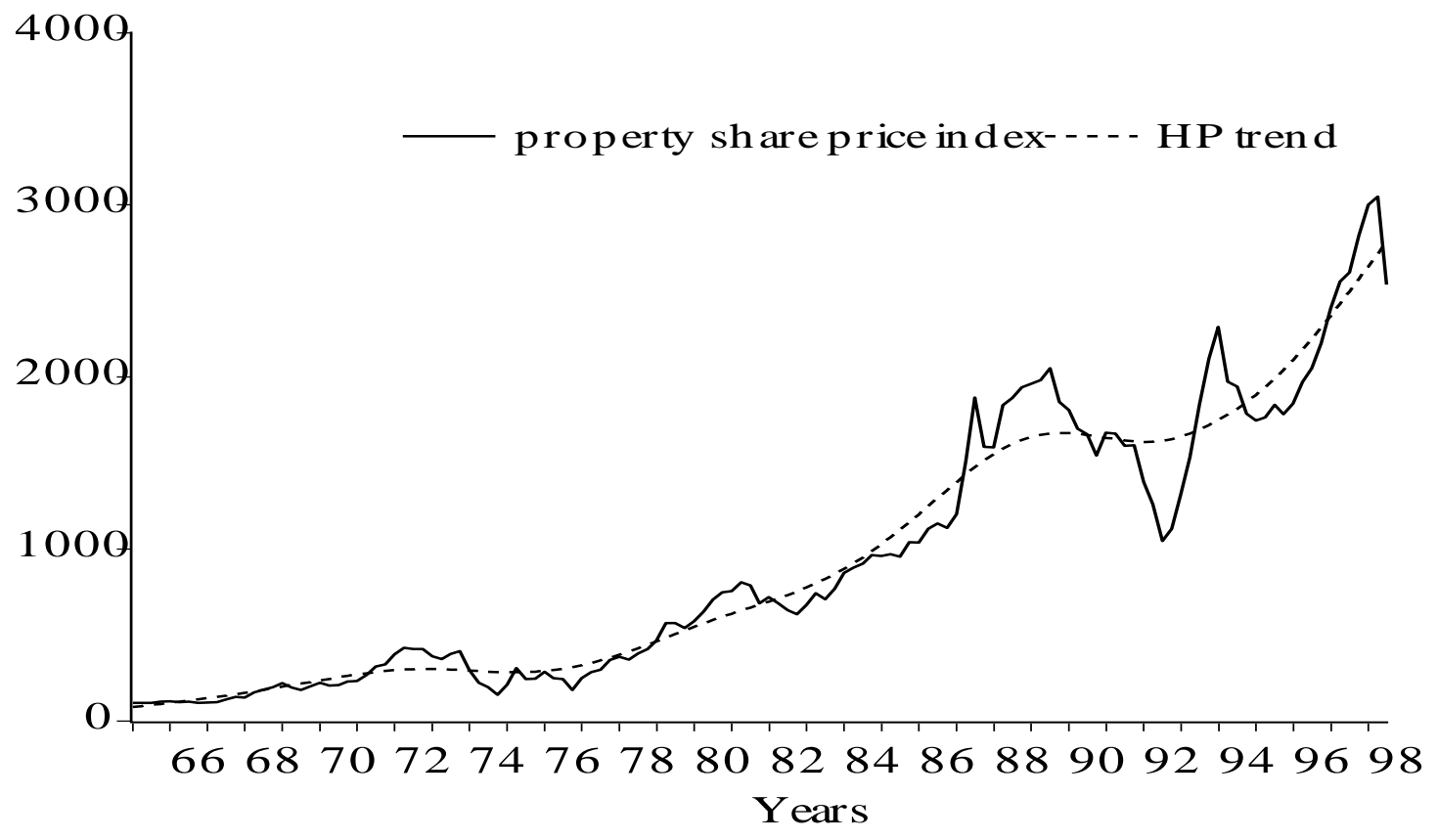


Figure 2. The HP cycle of property share prices in the UK

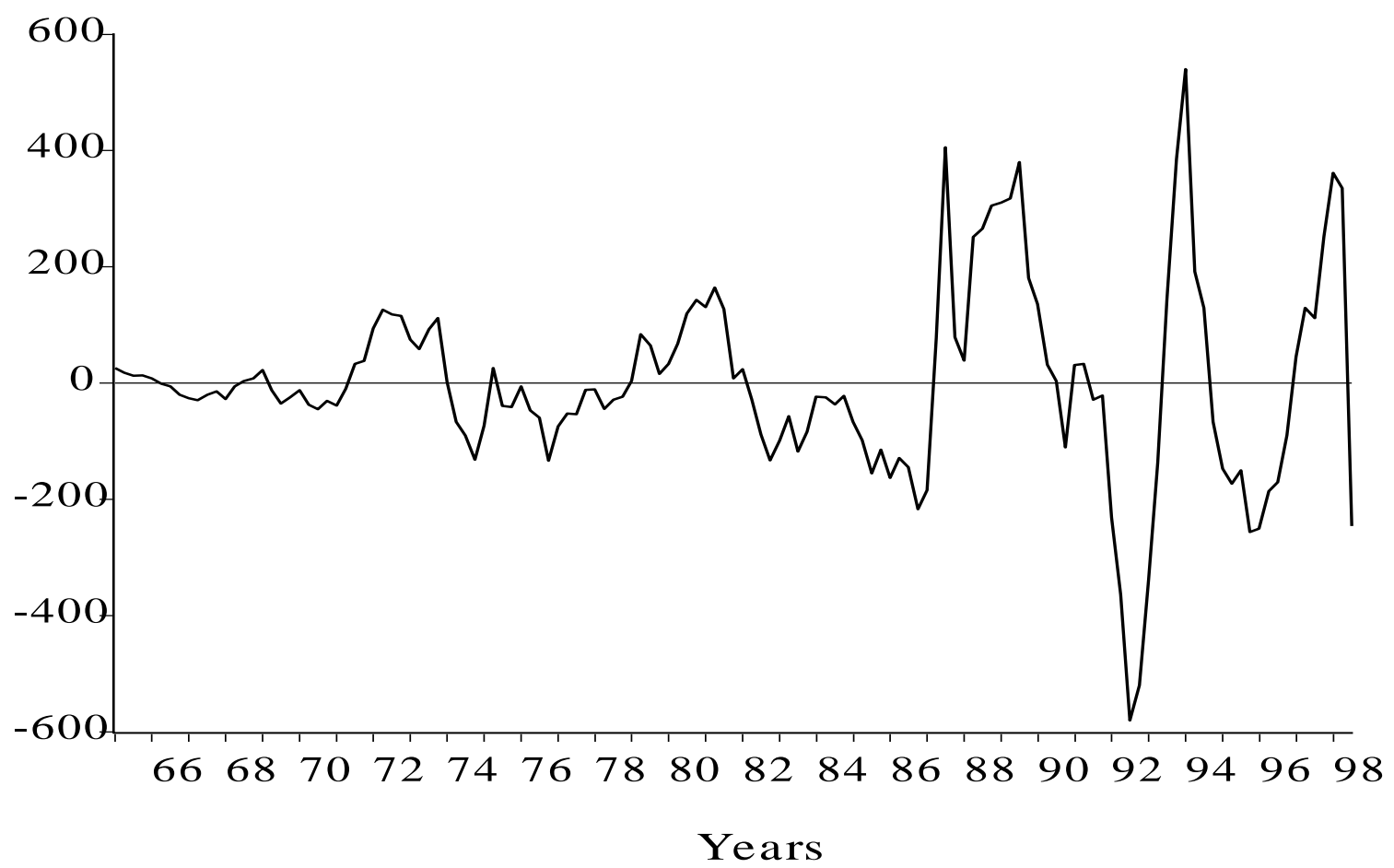

Figure 3 shows the HP GDP cycle which is produced in the same manner as the property stock price cycle in Figure 2. The graph illustrates three major cycles of 4-6 year duration two cycles in the 1970s and one in the late 1980s to early 1990s - when output exhibited significant oscillations. The main characteristic of the inflation cycle shown in Figure 4 is its more stable cyclical pattern in the 1990s compared with the high volatility that the inflation rate exhibited in the 1970s. Finally, Figure 5 shows the cycle of the Treasury Bill rate. The strong oscillations of the 1970s mirror the cycle of inflation in that period. Another significant short-term cycle that the Treasury Bill rate data exhibit is in the period 1989 to 1993. Since mid-1990s a more stable trend appears to emerge reflecting to a large extent the lower volatility in the rate of inflation. 
Figure 3. The HP GDP cycle

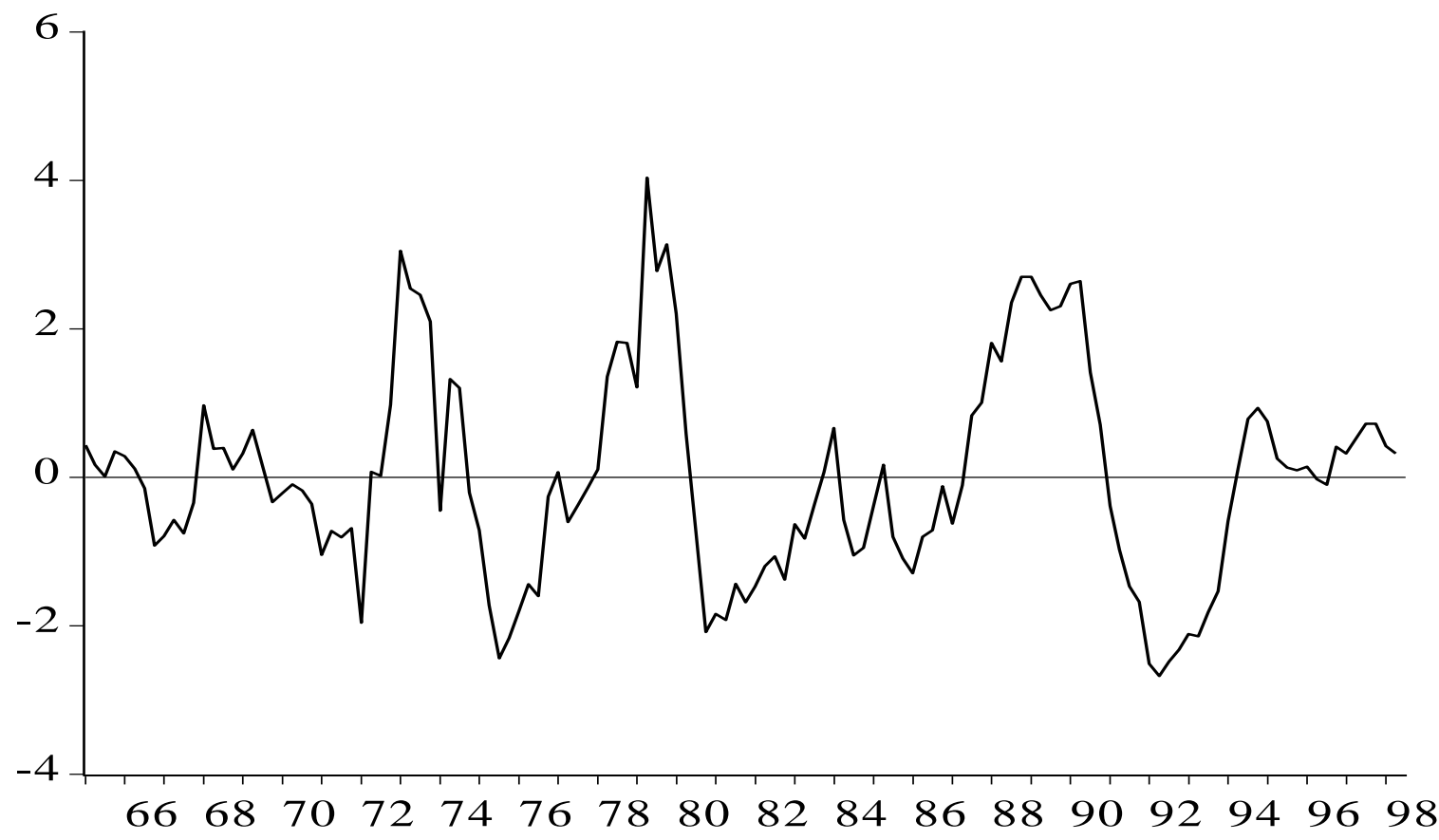

Figure 4. The HP inflation cycle

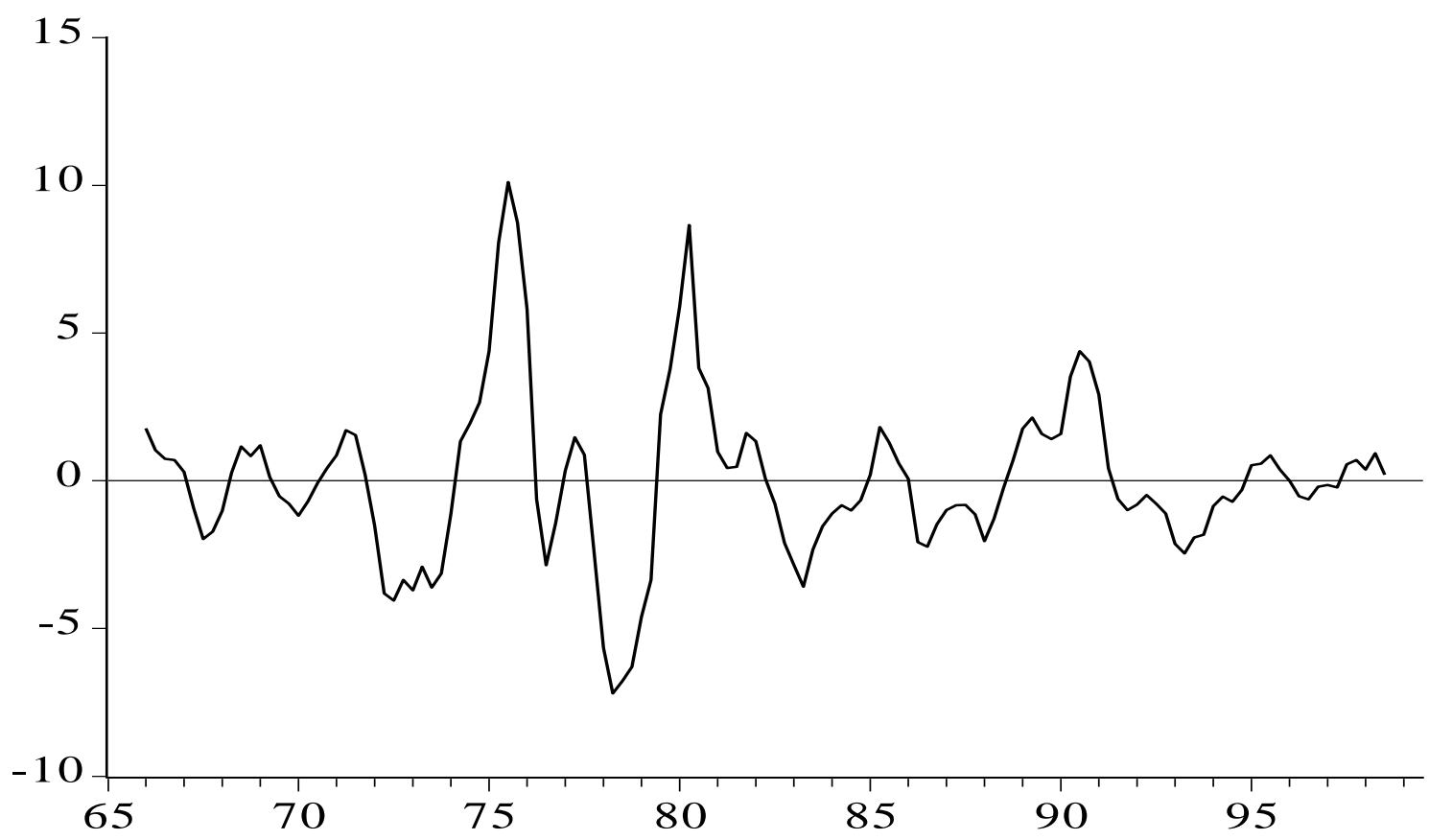


Figure 5. The HP Treasury Bill rate cycle

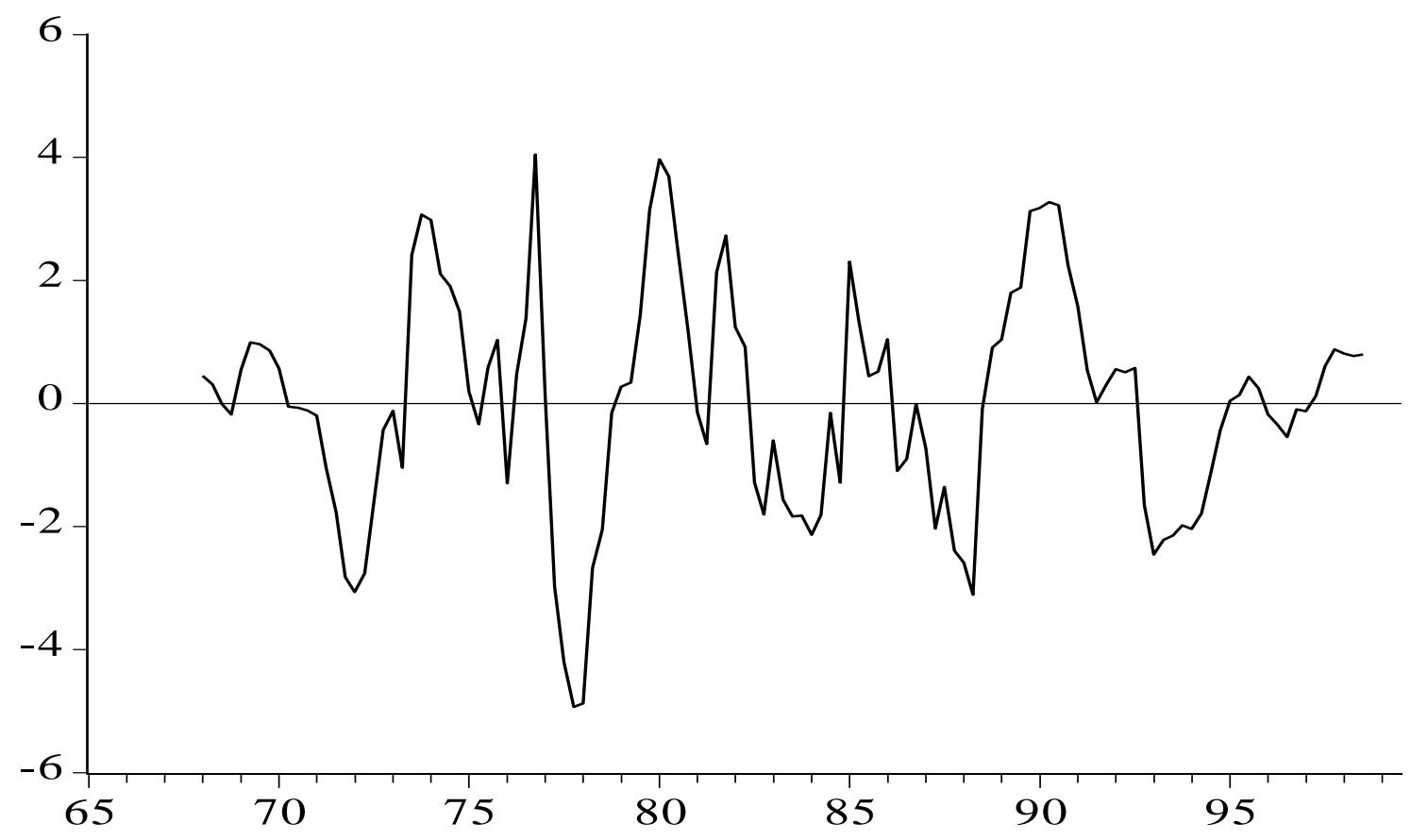

\section{Results}

This section presents the results of examining the cyclical regularities of the HP property stock price cycle with the HP cycles of all other variables. These cyclical co-movements between the cycles of the variables are summarised with cross-correlations. It is deemed appropriate, however, to apply the statistical measures of cross-corellations to stationary stochastic processes. For this purpose ADF tests for unit roots are carried out to the cyclical component (the HP cycle) of each series. The ADF regressions are run with a time trend and a drift. The choice of the lag length in these representations is accomplished by the commonly used in the applied econometrics literature Schwarz criterion (Schwarz, 1978). The results of the stationarity tests are reported in Table 1 . It is concluded that all variables are stationary at the five percent level of significance. 
Table 1. ADF statistics from stationarity tests on individual series

\begin{tabular}{lc}
\hline Variables & $t$-statistic \\
\hline PROPRICE & $-4.64 * *$ \\
PROPRICE\% & $-4.68 * *$ \\
GDP & $-4.37 * *$ \\
EXP & $-3.93 *$ \\
EXPH & $-3.92 *$ \\
INFL & $-5.67 * *$ \\
UNINFL & $-8.78 * *$ \\
DIVY & $-5.88 * *$ \\
TBILN & $-4.25 * *$ \\
TBR & $-6.89 * *$ \\
TBREX & $-6.80 * *$ \\
TBRRATIO & $-5.55 * *$ \\
$Y 2 O N$ & $-4.74 * *$ \\
SPREAD & $-4.45 * *$ \\
RRENT & $-4.09 * *$ \\
PROPY & $-3.48 *$ \\
\hline Notes: * and ** indicate significance at $5 \%$ and $1 \%$ levels respectively. & \\
&
\end{tabular}

Table 2. Real economy variables

\begin{tabular}{lccccccc}
\hline \multicolumn{1}{c}{ Cross correlations with PROPRICE at period t } \\
\hline & $\mathrm{t}-3$ & $\mathrm{t}-2$ & $\mathrm{t}-1$ & $\mathrm{t}$ & $\mathrm{t}+1$ & $\mathrm{t}+2$ & $\mathrm{t}+3$ \\
\hline GDP & 0.28 & 0.31 & 0.35 & 0.40 & 0.43 & $\mathbf{0 . 4 5}$ & 0.42 \\
EXP & 0.41 & 0.48 & 0.54 & $\mathbf{0 . 5 7}$ & 0.54 & 0.50 & 0.42 \\
EXPH & 0.40 & 0.46 & 0.53 & $\mathbf{0 . 5 6}$ & 0.52 & 0.48 & 0.41 \\
\hline
\end{tabular}

PROPRICE is the property stock share price index returns; GDP is the gross domestic product; $E X P$ is total consumer expenditure; $E X P H$ is total consumer expenditure per head. All variables represent the short-term cycle of their respective series; Sample period: $1965 q 1-1998 q 2$. All correlations in this table are significant at the $1 \%$ level.

Table 2 presents the results for the cross-correlations between real economy variables and the HP cycle of the property share price series. In this table, three lagged and three led values of the HP cycles of GDP, EXP and EXPH are correlated with the contemporaneous values of the HP property stock price series (the property stock price cycle). The largest correlation 
coefficients are shown in bold; in fact, all correlations in the table are significant at the $1 \%$ level. As expected, the cycle of the gross domestic product is positively correlated with the property share price cycle in all periods. Therefore, the GDP cycle is procyclical for property, suggesting that expansions (contractions) in economic activity correspond to higher (lower) prices in property stocks. Over the sample period the results show that the GDP cycle lags the property price cycle since the contemporaneous values of the latter are more strongly correlated with the led values of the GDP cycle than its lagged values. The strongest correlation with the contemporaneous values of the property share price cycle is at lead $t+2$. It is therefore inferred that economic information relating to the future cyclical trends of $G D P$ is already incorporated in the revisions of the property price series in the current period (which means that the latter adjusts in anticipation of GDP changes).

The total private expenditure and expenditure per head (EXP and EXPH) variables are procyclical, a finding that also conforms to a priori expectations. It is also consistent with empirical evidence suggesting that this variable helps explain property returns (Geltner, 1989; Ling and Naranjo, 1997). Unlike GDP, which lags the property cycle, the cross-correlation coefficients reveal that no phase shift is displayed in either direction over the sample period. The size of the coefficients on lagged and led values each quarter are broadly similar and the largest value of the cross-correlation coefficients is at time t. Thus it is concluded that the cycles of the consumption variables and the property share price cycle are coincident.

Although all three real economy variables are procyclical, overall the cross-correlations suggest that none of these variables lead the property price cycle. This implies a speedy incorporation of information (or at least within a quarter) reflecting the changing trends of economic series into property stock prices. It can be argued that this process of quick 
assimilation of economic information is enhanced by the adoption of more sophisticated techniques in the pricing of property stocks over time. The findings also suggest that the use of these real economy variables as leading indicators to predict trends in the price of property backed securities is not suitable. Structural models of property share price determination which assume explicit and strong precedence of these variables could be wrongly specified.

Table 3. Inflation variables and dividend yield

\begin{tabular}{lcccccccc}
\hline \multicolumn{8}{c}{ Cross correlations with PROPRICE\% at period t } \\
\hline & $\mathrm{t}-3$ & $\mathrm{t}-2$ & $\mathrm{t}-1$ & $\mathrm{t}$ & $\mathrm{t}+1$ & $\mathrm{t}+2$ & $\mathrm{t}+3$ \\
\hline INFL & -0.06 & 0.00 & -0.00 & -0.04 & -0.12 & $-0.21^{*}$ & $\mathbf{- 0 . 2 5 * *}$ \\
UNINFL & 0.02 & 0.07 & -0.02 & -0.07 & -0.12 & $\mathbf{- 0 . 1 4}$ & 0.04 \\
DIVY & $0.19 *$ & -0.04 & $-0.33^{* *}$ & $\mathbf{- 0 . 5 8 * *}$ & $-0.53^{* *}$ & $-0.41^{* *}$ & $-0.25^{* *}$ \\
\hline PROPRICE\% is PRORPRICE expressed in percentage terms. INFL is the annual inflation rate; \\
UNINFL is a measure of the unexpected annual inflation rate; DIVY is the all share dividend \\
yield; All variables represent the short-term cycle of their respective series; Sample period: \\
1966q1 - 1998q2; * and ** denote significance at the 5\% and 1\% levels respectively.
\end{tabular}

Table 3 reports the computed cross-correlation coefficients for the inflation and dividend yield variables. Lagged values of the inflation variables do not correlate with the contemporaneous values of property returns. Led values of the inflation series tend to show a weak negative correlation with the property stock price cycle. Overall, contrary to the expected procyclical relationship, the results appear to suggest a countercyclical relationship. However, the correlation coefficients are rather weak and any further meaningful analysis of this cyclical pattern cannot be made. Similarly the unexpected inflation cycle does not exhibit significant co-movements with the property share return cycle at any leads or lags. This contrasts with the results of Chan et al (1990) and Ling and Naranjo (1997) who have found a significant effect of unanticipated inflation on the predictable variation in property returns in the US. In the UK, Brooks and Tsolacos (1999) found only weak support for the inflation 
variables (realised and unexpected) and in addition their impact on property returns did not appear to be stable.

The dividend yield variable is clearly countercyclical with the property stock price cycle supporting the a priori relationship. The results show a rather strong contemporaneous correlation between these cycles. An inspection of the cross-correlation coefficients at lags t$1, t-2$ and at leads $t+1, t+2$ reveals a tendency for the dividend yield to lag the growth in property stock prices. However, the strongest correlation occurs contemporaneously suggesting that the cycles of property share price growth and the dividend yield are coincident. This is not surprising since it is expected that dividend yields and property share prices reflect broadly the same economic and financial fundamentals and should be determined contemporaneously. This finding is in line with the consistent influence of this variable on the performance of property backed assets that Chan et al (1990) detected in the US. On the other hand, Ling and Naranjo (1997) have found only weak evidence. 
Table 4. Interest rate variables

\begin{tabular}{|c|c|c|c|c|c|c|c|}
\hline & \multicolumn{7}{|c|}{ Cross correlations with PROPRICE\% at time $\mathrm{t}$} \\
\hline & $t-3$ & $t-2$ & $\mathrm{t}-1$ & $\mathrm{t}$ & $\mathrm{t}+1$ & $t+2$ & $t+3$ \\
\hline TBILN & $-0.30 * *$ & $-0.44 * *$ & $-0.48 * *$ & $-0.47 * *$ & $-0.32 * *$ & -0.12 & 0.08 \\
\hline$T B R$ & $-0.17 *$ & $-0.34 * *$ & $-0.36 * *$ & $-0.30 * *$ & -0.09 & $0.17 *$ & $0.35^{* *}$ \\
\hline TBREX & -0.15 & $-0.28 * *$ & $-0.33 * *$ & $-0.29 * *$ & -0.13 & 0.09 & $0.33 * *$ \\
\hline TBRRATIO & $0.22 *$ & $0.18 *$ & 0.14 & 0.04 & -0.03 & -0.06 & -0.06 \\
\hline$Y 20 N$ & -0.12 & $-0.31 * *$ & $-0.49 * *$ & $-0.57 * *$ & $-0.43 * *$ & $-0.23 * *$ & -0.07 \\
\hline SPREAD & $0.32 * *$ & $0.36^{* * *}$ & $0.29 * *$ & $0.20 *$ & 0.10 & -0.02 & -0.16 \\
\hline
\end{tabular}

Note: For the definition of PROPRICE\% see Table 3. TBILN is the nominal Treasury Bill rate; TBR is a measure of the real Treasury Bill rate defined as TBILN minus the annual realised rate of inflation; TBREX is another measure of the real Treasury Bill rate defined as TBILN minus the expected rate of inflation; TBRRATIO is a third measure of the real rate defined as the ratio of TBILN to the realised annual inflation rate. This variable is not in percentage terms and thus it is correlated with PROPRICE; Y2ON is the nominal yield on 20 year gilts; SPREAD is the difference between $Y 20 N$ and TBILN; All variables represent the short-term cycle of their respective series. Sample periods: TBILN, TBR, TBREX, TBRRATIO, SPREAD: 1968q1-1998q2; Y20N: 1966q1 - 1998q2; * and $* *$ denote significance at the $5 \%$ and $1 \%$ levels respectively.

Table 4 summarizes the results for the cross-correlations of the interest rate variables with the property price cycle. With the exception of the ratio measure of real interest rates (TBRRATIO), the nominal and real short-term interest rates exhibit counter-cyclical behaviour in relation to the property stock price cycle which is in accordance with a priori expectations. Of the three interest rate variables, the nominal interest rate cycle correlates more strongly with the property stock price growth cycle. It can also be observed that the highest correlation is at lag t-1. This means that the interest rate cycles lead the property price cycle by a quarter. The third real interest rate variable (TBRRATIO) can be regarded as counter-cyclical since the cross-correlations between $t-1$ and $t+3$ are negative. This cycle, however, lags the property share price cycle. The long-term interest rate cycle appears to correlate more strongly with the property share price cycle than the short-term interest rates at lags $t-1$ to $t+1$. The results show a clear counter-cyclical pattern, as it was expected. They also suggest that this relationship 
tends to be coincident. Our results also shed further light on the debate into the role of interest rates, as the existing empirical findings about the role for nominal or real interest rates in property return predictability are mixed. A number of studies have found supportive evidence (Chan et al, 1990; Ling and Naranjo, 1997; Lizieri and Satchell, 1997) but other studies have not found support for systematic effects (Chen and Tzang, 1988; Mueller and Pauley, 1995).

The interest rate spread cycle tends to exhibit a procyclical relationship with the property share return cycle although at lags $\mathrm{t}-3$ and $\mathrm{t}-2$ the correlations are negative. This supports the argument by Estrella and Hardouvelis (1991). Although the correlation-coefficients are small, this variable appears to lead the property return cycle by two quarters (correlation coefficient $=0.36)$. Therefore the view that this variable can be used as a leading indicator of business conditions receives support in this study but it should be noted that its cyclical correlation with the property return cycle is moderate. This is in line with the findings of Brooks and Tsolacos (1999), who used a VAR methodology and concluded that the term structure has an influence on the pricing of property stocks in the UK but that this relationship is not strong. Other evidence is conflicting. Chan et al (1990) suggest that the interest rate term structure can predict movements in property asset prices but the findings in the study of Liu and Mei (1992) did not confirm this. 
Table 5. Property market variables

\begin{tabular}{cccccccc}
\hline \multicolumn{7}{c}{ Cross correlations with PROPRICE\% at time t } \\
\hline RRENT & 0.14 & $0.27 * *$ & $0.39 * *$ & $0.50^{* *}$ & $0.56 * *$ & $0.58 * *$ & $\mathbf{0 . 5 9 * *}$ \\
PROPY & $0.38^{* *}$ & $0.42 * *$ & $0.26 * *$ & 0.03 & $-0.21 *$ & $-0.41 * *$ & $\mathbf{- 0 . 5 2 * *}$ \\
\hline
\end{tabular}

PROPRICE\% are defined in Table 3. RRENT is an index of property rents in real terms; PROPY is the all property yield.; All variables represent the short-term cycle of their respective series. Sample period: $1977 \mathrm{q} 2-1998 \mathrm{q} 2 ; *$ and $* *$ denote significance at the $5 \%$ and $1 \%$ levels respectively.

Table 5 reports the results for the property market variables. The real property rent cycle is procyclical but it clearly lags the property stock price cycle. This result suggests that investors discount in advance information relating to future changes in property rents. On the other hand, it is expected that rents will adjust to market conditions with a lag and at the time when they are renegotiated. In addition, the compilation of rent data may be subject to longer delays. This problem was expected to be mitigated to a degree by using the CB Hillier Parker rental data which, due to their definition, tend to lead other rent indices 5 .

The all property yield variable does not exhibit any clear pattern. The cross-correlation coefficients are positive at lags $t$ to $t-3$ and negative at $t+1$ to $t+3$. The strongest correlations, which have their expected signs, are computed at leads $t+2$ and $t+3$. This may suggest that the property yield cycle lags the property return cycle. This is somewhat a surprising result. It can be argued that at times when property yields change, property share prices respond

\footnotetext{
${ }^{5}$ Since the CB Hillier Parker data represent notional and rather prime properties the Jones Lang LaSalle (JLL) index was used as a rent series that is based on portfolios of real properties such as those underlying property stock prices. The results were very similar. The lagged values of the JLL index (in real terms) did not show any correlation with the contemporaneous values of the property stock price cycle. The highest correlation coefficients were obtained, as in the case of the CB Hillier Parker index, at leads $t+2$ and $t+3$ (cor.coef. at $t+2=0.51$ and at $t+3=0.54$ ). These similarities in the results were not surprising given that the HP cycles of both series are highly correlated (contemporaneous cor.coef. $=0.90$ ). When the series are used in nominal terms the overall results remain alike (but the magnitude of the correlation coefficients is smaller).
} 
simultaneously in order to incorporate the underlying new information. This response of property share prices appears to take place two quarters before property yields change. This could partly be attributable to the lag in the compilation of property yield data. Alternatively, the changing economic and market conditions which determine yield adjustments are discounted by incorporating all new information into the prices when property backed stocks are traded. The view that more sophisticated pricing techniques have led to speedier and more efficient incorporation of underlying information into the prices of property stock traded assets can explain these findings. In the US Mei and Liu (1994) examined the predictive power of the capitalisation rate and found that it is a significant variable for explaining the variation in returns on equity and mortgage property investment trusts in the US.

Tables 2 to 5 reported the cross-correlations between the property share price cycle and a set of aggregate time series over the full sample periods for each variable. An issue which arises is whether these cross-correlations are stable over time. In the existing literature, the possibility of a changing relationship between the property price or return cycle and the variables considered has not been examined. This implicit assumption of time invariant relationships may not represent the true dynamics of the cyclical relationships that researchers investigate. There is some evidence suggesting that the cyclical co-movements of the aggregate time-series and property stock prices are not invariant to the passage of time. For example, in the context of the UK, Lizieri and Satchell (1997), using a methodology that tests for non-linearities in economic relationships, argued that the effect of real interest rates on property company share prices is different in periods of high and low real interest rates.

It is, therefore, appropriate to examine within the framework of the existing study the stability of the cross-correlations reported in Tables 2 to 5. This can be done by examining the 
constancy of the correlation coefficients over the full sample period. The fact that the volatility of property stock prices before $1987 q 1$ was significantly less than post $1987 q 1$ (see Figure 2) necessitates stability tests. The stability of cross-correlations has been examined in the existing literature with the application of the Chow (1960) breakpoint test (see Blackburn and Ravn, 1992 and McGough and Tsolacos, 1997) and recursive estimates of the coefficients over the sample period (Blackburn and Ravn, 1992). In this study a recursive methodology is also used to test for the stability of the cross-correlations. Linear regressions are run of PROPRICE or PROPRICE\% on each of the aggregates using ever larger subsets of the sample data until all sample points have been used. Then the cumulative sum of squares test (CUSUMSQ) is applied to the residuals of these regressions. The results are given in Figure 6. In these plots, the expected value of the relevant test statistic is given under the hypothesis of parameter constancy. The five per cent critical bands are also shown. Movements of the line outside of the critical bands can be considered as an indication of instability. 
Figure 6: CUSUMSQ tests for cross-correlations stability
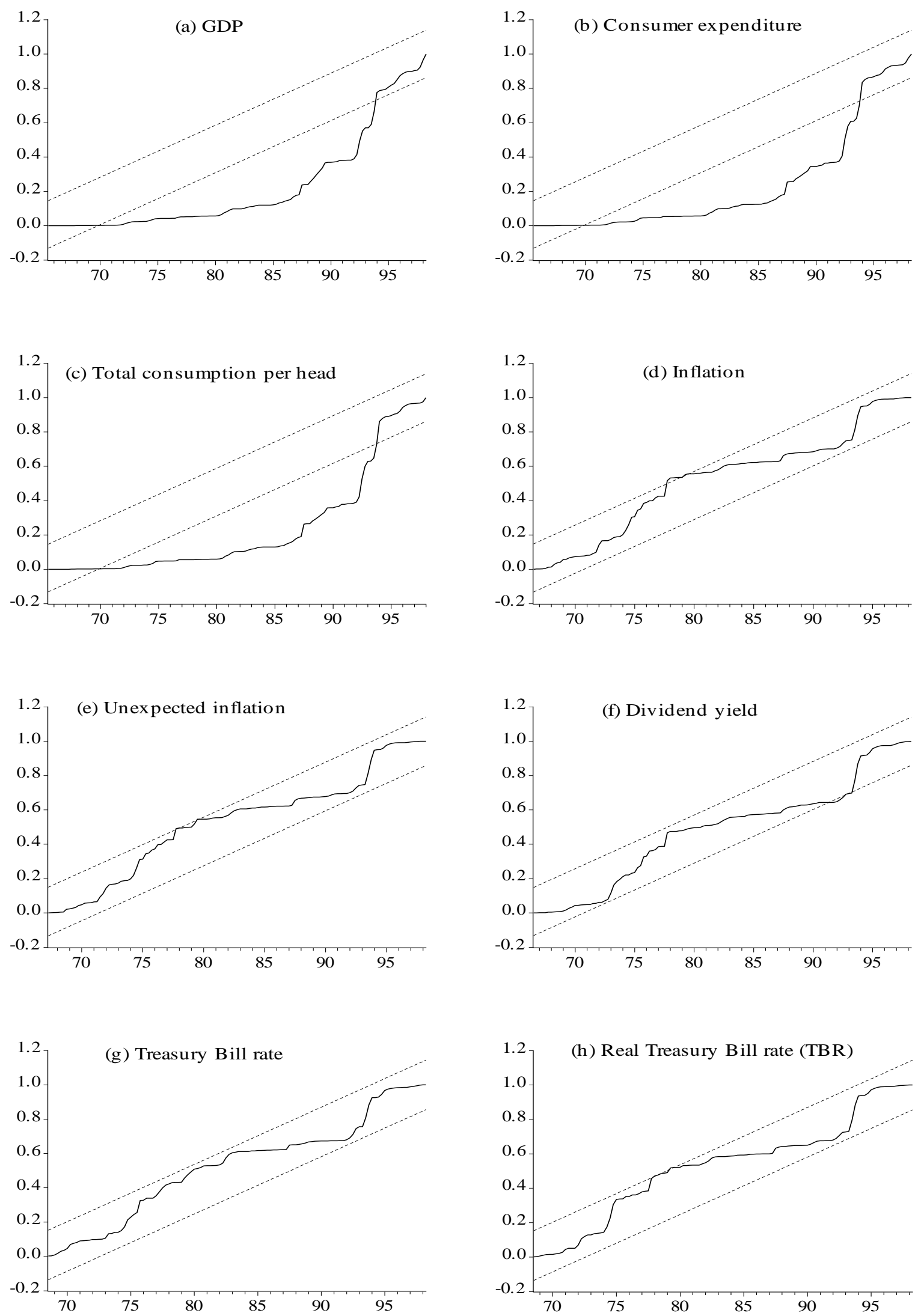

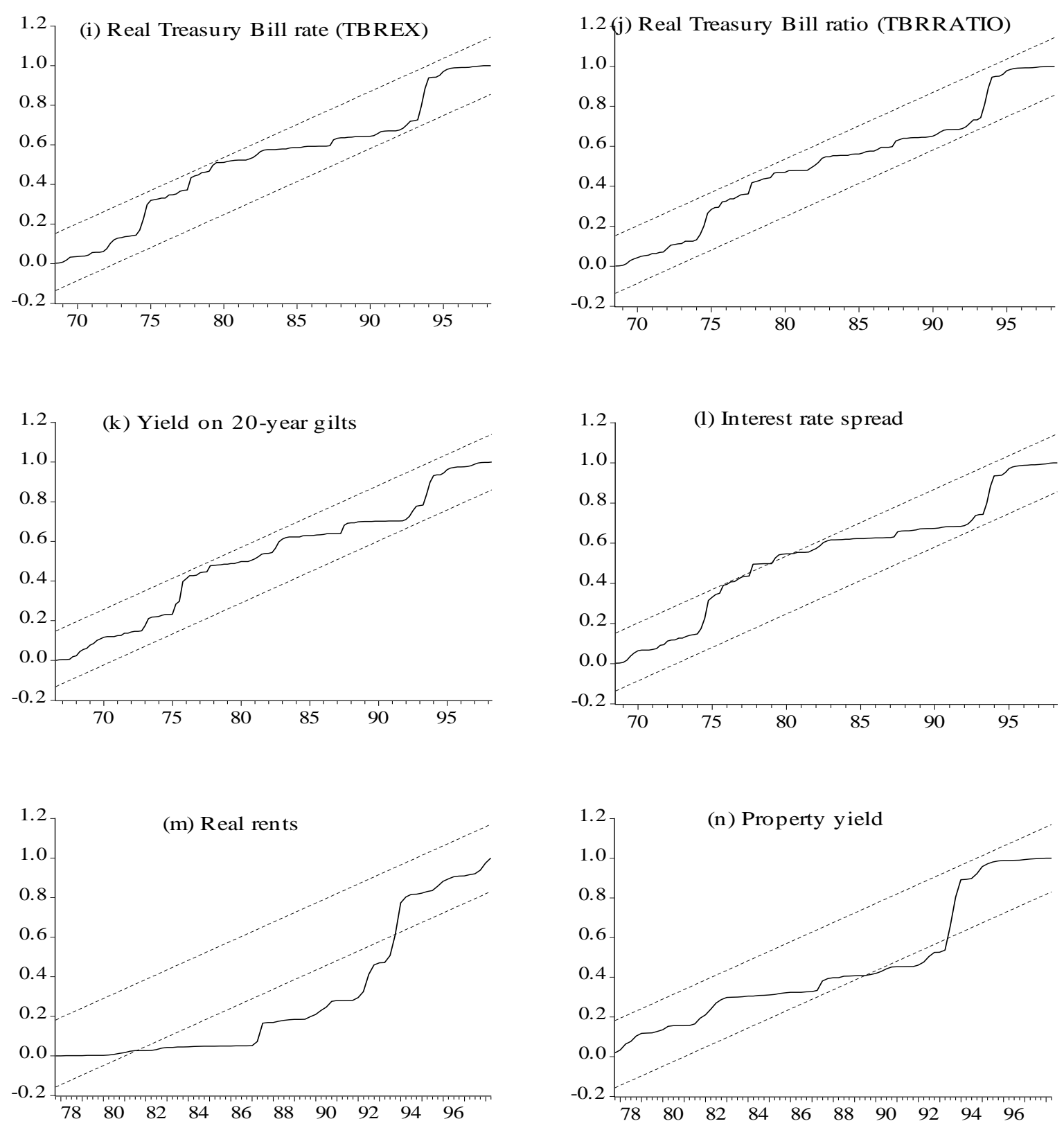

Panels (a) to (c) in Figure 6 show that all three real economy variables are unstable. The stability of the correlations between the cycles of these variables and the property stock price cycle begins to revert back into the bands at the beginning of 1987 the period when property stock prices started to show a greater variability. When the CUSUMSQ test is applied for the period 1987 quarter 1 to 1998 quarter 2 the test line remains within the bands. Therefore, the inclusion of the real economy variables in property stock price models is recommended only 
for the post 1986 period. The real rent and property yield cycles also show a break. As in the case of real economy variables, the test line for the former series moves towards the critical bands approximately in 1987. On the other hand, property yields show a small break but the relationship becomes stable at the beginning of 1990. The other cycles show tendencies for a break (unstable relationship) at certain periods but the, although the CUSUMSQ lines reach the upper or lower band, they remain within the five per cent significance boundaries.

\section{Conclusions}

A positive relationship between the broad economy and business conditions and the returns on real estate backed stocks has been argued in the existing, mainly US literature. Empirical evidence confirms that the variation in prices of property backed securities is closely linked to pre-determined macroeconomic and financial variables. It is expected, therefore, that in practice property stock prices and these variables should exhibit strong cyclical comovements. This study has sought to examine formally the cyclical properties of property stock prices and to conduct a statistical analysis of the cyclical regularities of aggregate time series, which are indicators of broad economic conditions and property market trends, and the price of property backed traded assets. This means that the relationships are studied without the causality assumptions that researchers make when they construct models of property stock prices and returns. Therefore, we establish a set of relationships which actually hold for the UK, rather than assuming and imposing the relationships a priori. The approach in this study is heavily based on the long tradition of research on the stylised facts of business cycles.

There are two main implications of this study for investment purposes. The first relates to the additional evidence that this study provides with regard to the variables that show movements that are cyclically related in the short-run to the prices of traded property stocks. The 
provision of such empirical evidence has been one of the main contributions of the existing literature to property investment analysis. The present study presents evidence in the UK context. It is found that the series of the real gross domestic product, the real consumer expenditure and the real consumer expenditure per capita are procyclical - that is, they move positively with the property price cycle in the UK. These correlations are not very strong, however, and stability tests showed that the cyclical variation in these variables and the property price cycle is stable only in the post-1987 period. The dividend yield shows a moderate relation to the property stock return cycle. The interest rate variables exhibit a weak to moderate countercyclical relationship to the property returns cycle. Finally, the expected procyclicality between the rent and property price cycles is established with UK data. The findings did not establish any marked cyclical regularity between the inflation and unexpected inflation series and the property stock return cycle. Furthermore, the results for property yields and property returns did not reveal the expected countercyclical relationship unless the former variable significantly lags the latter. Investors should consider these findings as the short run cyclical relationships (net of long-term trends) between property stock prices and a set of economic variables.

The second and more important implication of our results for investor, is a consideration of which variables of those that appeared procyclical or countercyclical, actually lead the property stock price or return cycle in the UK. The analysis did not identify any strong and long leading indicators of property stock prices or returns. The cycles of the gross domestic product, rents and property yields all lag the cyclical movements of property stock prices and returns. The widely used in existing work consumption variables, dividend yield and longterm interest rate series are found to be coincident with the property stock price cycle. With regard to the dividend yield, although the strongest correlation with the property return cycle 
is contemporaneous, the comparison of the lead and lag correlation coefficients reveals an element of lagged movements. It can, therefore, be concluded that information about the economy and the property market conveyed by these variables is incorporated speedily in the prices of property stocks. This is a sign of market efficiency. However, future estimates of the consumption variables in particular and the long-term interest rate can be used as inputs to an investigation of future movements of property stock prices and returns in the UK.

The analysis reveals that interest rates and the short-term interest rate spread seem to be leading indicators in the short-run. Although the cyclical correlations are moderate or even weak (and less strong than those of the consumption variables and the long-term interest rate) it is suggested that investors should include short-term interest rates and the interest rate spread in the set of variables that they monitor to make judgements about the future movements of property stock prices. In interpreting these results, the fact that quarterly data are used in this study should be taken into account; a study with monthly data may reveal stronger leading relationships but the main real economy variables are not available at this frequency.

There are also a number of implications for research on property stock prices and returns that is based on structural model methodologies. In accord with the findings of existing empirical studies, this study indicates that consumption variables are linked to the property price cycle. Their use in the structural modelling of this cycle in the context of the UK can only be significant after the beginning of 1987 when the relationship between the consumer expenditure variable and the property price cycle becomes stable. The present findings also suggest that the dividend yield can be included in structural modelling. On the other hand, it is doubtful to what extent property rents and property yields can explain the property price 
cycle given their significant lagged relationship with the contemporaneous values of property stock prices. The role for both short- and long-term interest rates in the UK property price context is worthy of further investigation given the rather moderate correlations obtained in this study. These variables may prove stronger leading indicators in other markets and of alternative property price and return series.

The stylised facts of the property stock price cycle, in terms of cyclical regularities with economic, financial and property market variables, can only be established if the study expands to other markets. This will benefit the work of both investors and researchers who are interested in testing alternative theoretical arguments in different market contexts. Research should aim to identify fundamental similarities in the co-movements between variables and property stock price cycles that is whether certain variables are procyclical or countercyclical and whether their cycle leads, lags or coincides with the property price cycles. The results from this exercise may differ across markets as a result of the idiosyncrasies in the national economic environments and nation-specific property market characteristics. What should also lie on the agenda for future research is the ability of the identified leading and coincident variables to predict more accurately trends and turning points in property stock price cycles across international markets. 


\section{References}

Backus, D. and Keohe, P. (1992) International evidence on the historical properties of business cycles, American Economic Review 82, 864-88.

Backus, D., Kehoe, P. and Kydland, F. (1992) International real business cycles, Journal of Political Economy 100(4), 745-75.

Beaudry, P. and Koop, G. (1993) Do recessions permanently change output?, Journal of Monetary Economics 31, 149-63.

Bernanke, B.S. (1990) On the predictive power of interest rates and interest rates spreads, New England Economic Review, November/December, 51-68.

Beveridge, S. and Nelson, C. (1981) A new approach to decomposition of economic time series into permanent and transitory components with particular attention to measurement of the 'business cycle', Journal of Monetary Economics 7, 151-174.

Blackburn, K. and Ravn, M. (1992) Business cycles in the United Kingdom: facts and fictions, Economica 59, 383-401.

Blanchard, O. and Quah, D. (1989) The dynamic effects of aggregate demand and supply disturbances, American Economic Review 79, 655-73.

Brandner, P. and Neusser, K. (1992) Business cycles in open economies: stylised facts for Austria and Germany, Weltwirtschaftliches Archiv 128, 67-87.

Breeden, D. (1979) An intertemporal asset pricing model with stochastic consumption and investment opportunities, Journal of Financial Economics 7, 256-96.

Breeden, D., Gibbons, M. and Litzenberger, R. (1989) Empirical tests of the consumption-orientated CAPM, Journal of Finance 44, 231-62.

Brooks, C. and Tsolacos, S. (1999) Property returns and the Macroeconomy, Journal of Property Research 16(2), 139-152

Chan, C.K., Hendershott, P.H. and Sanders, A.B. (1990) Risk and return on real estate: evidence from equity REITs, American Real Estate and Urban Economics Association Journal 18, 431-52.

Chen, K.C. and Tzang, D.D. (1988) Interest rate sensitivity of real investment trusts, Journal of Real Estate Research 3(3), 13-22.

Chen, N., Roll, R. and Ross, S. (1986) Economic forces and the stock market, Journal of Business 59, 383-403.

Chen, N-F (1991) Financial investment opportunities and the macroeconomy, Journal of Finance 46(2), 529-54.

Chow, G. (1960) Tests on equality between sets of coefficients in two linear regressions, Econometrica 28(3), 591-605.

Chung, P. and Zhou, Z-g. (1996) The predictability of stock returns - a nonparametric approach, Econometric Reviews 15(3), 299-330.

Danthine, J.P. and Girardin, M. (1989) Business cycles in Switzerland: a comparative study, European Economic Review 33, 31-50.

Davis, E.P. and Hendry, S.G.B. (1993) The use of financial spreads as indicators of real activity, in Money and Banking: Issues for the twenty-first century edited by P. Arestis, Macmillan London. 
Dickey, D. A. and W.A. Fuller (1981) Likelihood ratio statistics for autoregressive time series with a unit root, Econometrica 49, 1057-72.

Dickey, D. A. and W.A. Fuller (1979) Distribution of the estimators for autoregressive time-series with a unit root, Journal of the American Statistical Association 74, 427-31.

Eichholtz, P., Hoesli, M., MacGregor, B. and Nanthakumaran, N. (1995) Real estate portfolio diversification by property type and region, Journal of Property Finance 6(3), 39-59.

Eppli, M.J., Shilling, J.D. and Vandell, K.D. (1998) What moves retail property returns at the metropolitan level?, Journal of Real Estate Finance and Economics 16(3), 317-42.

Estrella, A. and Hardouvelis, G. (1991) The term structure as a predictor of real economic activity, Journal of Finance 46(2), 555-76.

Fama, E. (1981) Stock returns, real activity, inflation and money, American Economic Review 71, 545-65.

Fama, E.F. and French, K.R. (1988) Dividend yields and expected stock returns, Journal of Financial Economics 22, 3-25

Fama, E.F. and French, K.R. (1989) Business conditions and expected returns on stocks and bonds, Journal of Financial Economics 25, 427-65.

Fama, E.F. and French, K.R. (1992) The cross-section of expected stock returns, Journal of Finance 47, 427-65.

Ferson, W. (1983) Expected real interest rates and consumption in efficient financial markets: empirical tests, Journal of Financial and Quantitative Analysis 18, 477-98.

Ferson, W. and Harvey, C. (1991) The variation of economic risk premiums, Journal of Political Economy 99, 385-415.

Geltner, D. (1989) Estimating real estate's systematic risk from aggregate level appraisal-based returns, Journal of the American Real Estate and Urban Economics Association 17, 463-81.

Hansen, L. and Singleton, K. (1983) Stochastic consumption, risk aversion, and the temporary behaviour of asset returns, Journal of Political Economy 91, 249-65.

Hardouvelis, G. (1994) The term structure spread and future changes in long and short rates in the G7 countries, Journal of Monetary Economics 33, 255-83.

Hodrick, R. and Prescott, E. (1980) Poswar US business cycles: an empirical investigation, mimeo, Carnegie Mellon University, Pittsburgh, PA.

Hoesli, M., Lizieri, C. and MacGregor, B. (1997) The spatial dimensions of the investment performance of UK commercial property, Urban Studies 34(9), 1475-94

King, R.G. and Rebello, S.T. (1993) Low frequency filtering and real business cycles, Journal of Economic Dynamics and Control 17, 207-31.

Kydland, F. and Prescott, E. (1990) Business cycles: real facts and monetary myth, Quarterly Review, Federal Reserve Bank of Minneapolis 14(2), 3-18.

Laurent, R.D. (1988) An interest-based indicator of monetary policy, Economic Perspective, Federal Reserve Bank of Chicago, January/February, 3-14.

Ling, D. and Naranjo, A. (1997) Economic risk factors and commercial real estate returns, Journal of Real Estate Finance and Economics 14(3), 283-307. 
Liu, C.H. and Mei, J. (1992) The predictability of returns on equity REITs and their co-movement with other assets, Journal of Real Estate Finance and Economics 5, 401-18.

Lizieri, C. and Satchell, S. (1997) Property company performance and real interest rates: a regime switching approach, Journal of Property Research 14, 85-97.

McCue, T.E. and Kling, J.L. (1994) Real estate returns and the macroeconomy: some empirical evidence from real estate investment trust data, 1972-1991, Journal of Real Estate Research 9(3), 5-32.

Mei, J and Liu, C.H. (1994) The predictability of real estate returns and market timing, Journal of Real Estate Finance and Economics 8, 115-35.

Mueller,G. and Pauley, K. (1995) The effect of interest-rate movements on real estate investment trusts, Journal of Real Estate Research 10(5), 319-25.

Nelson, C. and Plosser, C. (1982) Trends and random walks in macroeconomic time series, Journal of Monetary Economics 10, 139-62.

Pesaran, H.M. and Timmermann, A. (1995) Predictability of stock returns: robustness and economic significance, Journal of Finance L(4), 1201-28.

Peterson, J.D. and Hsieh, C-H (1997) Do common risk factors in the returns on stocks and bonds explain returns on REITs?, Real Estate Economics 25(2), 321-45.

RICS (1994) Economic Cycles and Property Cycles: Final Report, London: Royal Institution of Chartered Surveyors.

Roll, S. and Ross, S. (1980) An empirical investigation of the arbitrage pricing theory, Journal of Finance 35, 1073-1163.

Shapiro, M. and Watson, M. (1988) Sources of business cycle fluctuations, NBER Macroeconomic Annual 1988 3, 111-56.

Schwarz, G. (1978) Estimating the dimension of a model, Annals of Statistics 6, 461-64.

Stock, J. and Watson, M. (1990) Business cycles properties of selected US economic time series 1959-1988, WP-3376, National Bureau of Economic Research, Cambridge, MA.

Stock, J. and Watson M. (1989) New indexes of coincident and leading economic indicators, in NBER Macroeconomic Annual edited by S.Fischer and O.Blanchard, MIT Press, Cambridge, MA.

Woitek, U. (1996) The G7 countries: a multivariate description of the business cycle stylised facts, in Dynamic Disequilibrium Modelling: Theory and Applications edited by W.A. Barnett, E. Gandolfo and C.Hillinger, Cambridge University Press, Cambridge, UK, 283-309. 